\title{
COMPARING THE APPLICATION OF THE ISLAMIC LAW OF SUCCESSION AND ADMINISTRATION OF ESTATES IN SINGAPORE AND SOUTH AFRICA
}

\author{
Muneer Abduroaf \\ LLB (Sharee'ah) LLB LLM LLD \\ Senior Lecturer, Department of Criminal Justice \\ and Procedure, University of the Western Cape
}

\section{SUMMARY}

This article investigates how the Islamic law of succession and administration of estates is applied in Singapore and South Africa with regard to the "Islamic will". This kind of will includes a provision where the testator or testatrix states that his or her estate must be distributed in terms of the Islamic law of succession. This requires an Islamic law expert or an Islamic organisation to draft an Islamic distribution certificate stating who the beneficiaries of the person are. The distribution certificate is drafted after the testator or testatrix has died. An Islamic distribution certificate within the Singaporean context is specifically compared with one in the South African context. This article looks at whether features found in the Singaporean model can be applied to the South African context. An overview of the Muslim population in Singapore and South Africa is presented by way of introduction. This is followed by an examination of the constitutional and international obligations of the two countries in light of their equality provisions, and a comparative analysis of the Islamic law of succession and administration of estates in the two countries. The focus areas looked at are liability claims, testate succession claims and intestate succession claims. A brief analysis of the findings and concluding remarks are made at the end of the article.

\section{INTRODUCTION}

This article investigates how the Islamic law of succession and administration of estates is applied in Singapore and South Africa. It compares the Singaporean model with the South African model with regard to the "Islamic will", which includes a provision where the testator or testatrix states that his or her estate must be distributed in terms of the Islamic law of succession. This requires an Islamic law expert or an Islamic organisation to draft an Islamic distribution certificate stating who the beneficiaries of the 
person are. ${ }^{1}$ The distribution certificate is drafted after the testator or testatrix has died. The Islamic distribution certificate in the Singaporean context is specifically compared with one in the South African context. This paper looks at whether features found in the Singaporean model can be applied to the South African context. Singapore has been chosen as a comparative country as it is quite similar to South Africa in the following respects: South Africa and Singapore are both Muslim-minority countries; ${ }^{2}$ both countries have a large group of Muslims who follow the Sunnee-based Shaafi'ee school of law; ${ }^{3}$ both countries are governed by constitutions that include equality provisions; and lastly, both countries have ratified the Convention on the Elimination of All Forms of Discrimination Against Women (CEDAW). ${ }^{4}$

An overview of the Muslim population in Singapore and South Africa is presented by way of introduction. This is followed by an examination of the constitutional and international obligations of the two countries in light of their equality provisions. This is followed by a comparative analysis of the Islamic law of succession and administration of estates in the two countries. The focus areas looked at are liability claims, testate succession claims and intestate succession claims. A brief analysis of the findings and concluding remarks are made at the end of this article.

\section{$2 \quad$ MUSLIM POPULATION}

Singapore is a Muslim-minority country where Muslims constitute 15 per cent of the total population. The dominant school of law followed by Singaporean Muslims is the Sunnee-based Shaafi'ee school of law. ${ }^{5}$ This is

1 The Muslim Judicial Council (SA) is an Islamic organisation based in the Western Cape, South Africa. It provides the service of drafting Islamic distribution certificates based on Islamic wills, at a minimal charge of R300. See Dante "Distribution Certificates (Estates)" (2016) http://mjc.org.za/2016/06/14/distribution-certificates-estates/ (accessed 2017-10-20).

2 South Africa is a multicultural society comprising Black Africans (who constitute 80,7 per cent of the population), Coloureds (8,8 per cent), Indians and Asians (2,5 per cent), and Whites (8 per cent). See Statistics South Africa "Mid-Year Population Estimates 2017" http://www.statssa.gov.za/ (accessed 2017-12-18). Singapore is also a multicultural society comprising Chinese (who constitute 74,1 per cent of the population), Malays (13,4 per cent) Indians (9,2 per cent) and others (3,3 per cent). The "others" category comprises Eurasians, Caucasians, Arabs and Japanese. See Steiner "Governing Islam: The State, the Administration of Muslim Law Act (AMLA) and Islam in Singapore" 2016 16(1)(6) Australian Journal of Asian Law 1.

3 This school of law find its basis in the Sharee'ah, which comprises two primary sources known as the Quraan and Sunnah. The interpretation of these sources has resulted in the introduction of various schools of law. The four dominant schools of law followed by Muslims are the Sunnee-based Hanafee, Shaafi'ee, Maalikee, and Hanbalee schools of law. See Abduroaf "Islamic Law Mode of Estate Distribution in South Africa" 2016 International Survey of Family Law 458-461 for a further discussion on this issue.

4 CEDAW was adopted by the United Nations General Assembly Resolution 34/180 of 18 December 1979.

5 See Musawah “Thematic Report on Article 16, Muslim Family Law and Muslim Women's Rights in Singapore: 68th CEDAW Session Geneva, Switzerland" (2017) https://www.google.co.za/url?sa=t\&rct=j\&q=\&esrc=s\&source=web\&cd=2\&cad=rja\& uact=8\&ved=0ahUKEwjxhPucrenXAhWGXBoKHctfCLkQFgg4MAE\&url=http\%3A\%2F\%2Fw ww.musawah.org\%2Fsites\%2Fdefault\%2Ffiles\%2FSingapore\%2520-\%2520Musawah\% 2520Thematic\%2520Report\%2520for\%252068th\%2520CEDAW.compressed.pdf\&usg=AO vVaw2KkkEJOfjBALC6PmDj2Pgo (accessed 2017-12-01). 
similar to the South African position where the Sunnee-based Shaafi'ee school of law is one of the two dominant schools of law followed by Muslims living in South Africa. Muslims constitute approximately 1,5 per cent of the South African population. ${ }^{6}$

\section{CONSTITUTIONAL OBLIGATIONS}

Application of the Islamic law of intestate succession could be problematic in countries that promote equality and prohibit discrimination between males and females. In terms of the Islamic law of intestate succession, a daughter always inherits half the share of a son. Singapore and South Africa are bound by equality provisions in terms of their constitutional and international law obligations. Article 12(1) of the Constitution of the Republic of Singapore (the Singaporean Constitution) states:

"All persons are equal before the law and entitled to the equal protection of the law."

Section 9(1) of the Constitution of the Republic of South Africa (the South African Constitution) states:

"Everyone is equal before the law and has the right to equal protection and benefit of the law."

The provisions found in the two constitutions are almost identical in this regard. Article 12(2) of the Singaporean Constitution states:

"Except as expressly authorised by this Constitution, there shall be no discrimination against citizens of Singapore on the ground only of religion, race, descent or place of birth in any law and guarantees equal protection of all before and of the law and prohibits discrimination on the grounds of religion, race, descent or place of birth."

Section 9(3) of the South African Constitution prohibits unfair discrimination based on "race, gender, sex, pregnancy, marital status, ethnic or social origin, colour, sexual orientation, age, disability, religion, conscience, belief, culture, language and birth." While the Singaporean Constitution does not specifically prohibit discrimination based on sex and/or gender, the South African Constitution expressly prohibits discrimination based on sex and/or gender. The application of the Islamic law of intestate succession can therefore be constitutionally challenged in terms of the South African Constitution on the basis of discrimination on the grounds of sex and gender, whereas it cannot be specifically challenged on these grounds in

6 Moosa Unveiling the Mind: The Legal Position of Women in Islam: A South African Context 2ed (2011) 146. These are the latest population census figures regarding religion. The Muslim Judicial Council (SA), based in the Western Cape, "raised concerns regarding the exclusion of religious questions from the census [2011] questionnaire, [but] they still pledged their support" (Mangxamba "Stats SA meets Faith Based Organisations on Census 2011" (2011) http://www.statssa.gov.za/?page_id=3970 (accessed 2017-12-18)).

7 See also Bin Abbas "The Islamic Legal System in Singapore" 2012 21(1) Pacific Rim Law \& Policy Journal 163. 
terms of the Singaporean Constitution. Section 36(1) of the South African Constitution states:

"The rights in the Bill of Rights may be limited only in terms of law of general application to the extent that the limitation is reasonable and justifiable in an open and democratic society based on human dignity, equality and freedom."

The right to freedom of religion is expressly listed in the Singaporean Constitution. Article 15(1) states:

"Every person has the right to profess and practise his religion and to propagate it."

Section 15(1) of the South African Constitution states:

"Everyone has the right to freedom of conscience, religion, thought, belief and opinion."

The right to freedom of religion is found expressly in both the Singaporean and South African Constitutions. It could be argued that the right to freedom of religion should include the right to execute an Islamic will. This has been confirmed in Singaporean legislation, where article 110 of the Administration of Muslim Law Act ${ }^{9}$ (AMLA) states:

"Nothing in this Act shall be held to prevent any Muslim person directing by his or her will that his or her estate and effects shall be distributed according to the Muslim law."

There is no legislation regulating the Islamic law of succession in South Africa. The South African Law Reform Commission has advised that South African Muslims can execute wills in order to ensure that the Islamic law of succession applies to their estates.

Article 153 of the Singaporean Constitution states:

"The Legislature shall by law make provision for regulating Muslim religious affairs."

It could therefore be said that there is an indirect constitutional obligation on the Singaporean legislature to enact legislation governing the Islamic law of succession in terms of article 153 as this would be included in Muslim religious affairs. ${ }^{11}$ Article $12(3)$ of the Singaporean Constitution further permits different personal laws based on religious belief. ${ }^{12}$ The South African

8 S 36(1) of the South African Constitution goes on to state that rights may only be limited "taking into account all relevant factors, including - $(a)$ the nature of the right; $(b)$ the importance of the purpose of the limitation; $(c)$ the nature and extent of the limitation; $(d)$ the relation between the limitation and its purpose; and $(e)$ less restrictive means to achieve the purpose". Subsection 2 states: "Except as provided in subsection (1) or in any other provision of the Constitution, no law may limit any right entrenched in the Bill of Rights."

27 of 1966.

10 See also Bin Abbas 2012 Pacific Rim Law \& Policy Journal 177.

11 See Bin Abbas 2012 Pacific Rim Law \& Policy Journal 165.

12 Art 12(3) of the Singaporean Constitution states: "This Article does not invalidate or prohibit - (a) any provision regulating personal law; or (b) any provision or practice restricting office or employment connected with the affairs of any religion, or of an institution managed by a 
Constitution does not prevent the enactment of legislation governing religious law. However, legislation must be consistent with the Constitution of South Africa. ${ }^{13}$ The wording found in the South African Constitution is less demanding on the legislature than the wording found in the Singaporean Constitution with regard to the enactment of legislation regulating Muslim religious affairs. This could, however, be based on historical and political factors. The enactment of the Islamic law of succession in the South African context would be subject to the equality provisions in section 9(3) of the South African Constitution, which specifically prohibits unfair discrimination based on sex and/or gender. ${ }^{14}$ Discrimination based on the grounds of sex and/or gender is presumed to be unfair. ${ }^{15}$

\section{INTERNATIONAL LAW OBLIGATIONS}

Singapore ratified CEDAW on 5 October $1995 .{ }^{16}$ South Africa ratified CEDAW approximately two months later on 15 December $1995 .{ }^{17}$ Article 2 of CEDAW states that States Parties to the Convention "agree to pursue by all appropriate means and without delay a policy of eliminating discrimination against women". ${ }^{18}$ Article $16(1)$ of CEDAW specifically provides that States Parties to the Convention:

group professing any religion, to persons professing that religion." See also Bin Abbas 2012 Pacific Rim Law \& Policy Journal 165.

13 S 15(3)(a) of the South African Constitution states: "This section does not prevent legislation recognizing - (i) marriages concluded under any tradition, or a system of religious, personal or family law; or (ii) systems of personal and family law under any tradition, or adhered to by persons professing a particular religion." $S 15(3)(b)$ states: "Recognition in terms of paragraph (a) must be consistent with this section and the other provisions of the Constitution."

14 See s 9 of the South African Constitution: "(3) The state may not unfairly discriminate directly or indirectly against anyone on one or more grounds, including race, gender, sex, pregnancy, marital status, ethnic or social origin, colour, sexual orientation, age, disability, religion, conscience, belief, culture, language and birth. (4) No person may unfairly discriminate directly or indirectly against anyone on one or more grounds in terms of subsection (3). National legislation must be enacted to prevent or prohibit unfair discrimination."

15 See s 9(5) of the South African Constitution: "Discrimination on one or more of the grounds listed in subsection (3) is unfair unless it is established that the discrimination is fair."

16 See United Nations Treaty Collection https://treaties.un.org/Pages/ViewDetails.aspx?src $=$ TREATY\&mtdsg_no=IV-8\&chapter=4\&lang=en\#58 (accessed 2017-11-21).

17 CEDAW was adopted by the United Nations General Assembly Resolution 34/180 of 18 December 1979, signed by South Africa on 29 January 1993, and ratified on 15 December 1995.

18 Art 2 of CEDAW states further that States Parties "to this end, undertake: (a) To embody the principle of the equality of men and women in their national constitutions or other appropriate legislation if not yet incorporated therein and to ensure, through law and other appropriate means, the practical realization of this principle; (b) To adopt appropriate legislative and other measures, including sanctions where appropriate, prohibiting all discrimination against women; (c) To establish legal protection of the rights of women on an equal basis with men and to ensure through competent national tribunals and other public institutions the effective protection of women against any act of discrimination; (d) To refrain from engaging in any act or practice of discrimination against women and to ensure that public authorities and institutions shall act in conformity with this obligation; (e) To take all appropriate measures to eliminate discrimination against women by any person, 
"shall take all appropriate measures to eliminate discrimination against women in all matters relating to marriage and family relations and in particular shall ensure, on a basis of equality of men and women: ... (h) The same rights for both spouses in respect of the ownership, acquisition, management, administration, enjoyment and disposition of property, whether free of charge or for a valuable consideration."

The fact that a daughter inherits half the share of a son in terms of the Islamic law of intestate succession if they inherit collectively could be problematic with regard to articles 2 and 16 of CEDAW, which prohibits discrimination against women. ${ }^{19}$ Singapore made a few reservations regarding articles 2 and 16 of CEDAW in the following terms:

"In the context of Singapore's multi-racial and multi-religious society and the need to respect the freedom of minorities to practise their religious and personal laws, the Republic of Singapore reserves the right not to apply the provisions of articles 2 and 16 where compliance with these provisions would be contrary to their religious or personal laws.

This is also the situation in many Muslim countries where Islamic reservations to Human Rights Conventions have been made. ${ }^{21}$ To date, South Africa has not made any reservations to CEDAW.

The South African government ratified the Protocol to the African Charter on Human and Peoples' Rights on the Rights of Women in Africa (African WR Protocol) on 17 December $2004 .^{22}$ Article $21(2)$ of the African WR Protocol states:

"Women and men shall have the right to inherit, in equitable shares, their parents' properties."

South Africa has further enacted the Promotion of Equality and Prevention of Unfair Discrimination Act ${ }^{23}$ (PEPUDA), which is in line with CEDAW and the African WR Protocol.

It can be seen from the above that Singapore places more importance on the right to freedom of religion than on the right to equality. This can clearly be seen by the reservations made by the Singaporean government with regard to articles 2 and 16 of CEDAW. The South African government, on

organization or enterprise; (f) To take all appropriate measures, including legislation, to modify or abolish existing laws, regulations, customs and practices which constitute discrimination against women; (g) To repeal all national penal provisions which constitute discrimination against women."

19 It should be noted that a daughter would indirectly inherit more favourably than a son in the event where, for example, $X$ dies leaving behind a mother, a father, a widower, and a child as the only intestate beneficiaries. The child would inherit more favourably if female and less favourably if male.

20 UN Women "Declarations, Reservations and Objections to CEDAW" http://www.un.org/ womenwatch/daw/cedaw/reservations-country.htm (accessed 2017-01-08). See also Steiner 2016 Australian Journal of Asian Law 11.

21 See Mayer "Islamic Reservations to Human Rights Conventions" 199815 Recht van de Islam 25-45 for a discussion on this issue.

22 South Africa deposited the instrument of ratification on 14 January 2005.

234 of 2000 . 
the other hand, has enacted legislation that is in line with the human-rights requirements in terms of CEDAW and the African WR Protocol. The South African government might have to make reservations to the international and regional treaties and amend PEPUDA if it intends enacting legislation that regulates the Islamic law of succession and administration of estates in the South African context.

\section{REGULATION OF THE ISLAMIC LAW OF SUCCESSION AND ADMINISTRATION OF ESTATES}

There are two Acts that regulate the law of succession in Singapore. They are $\mathrm{AMLA}^{24}$ and the Intestate Succession Act (ISA) ${ }^{25}$ AMLA governs the administration of estates of deceased Muslims whereas ISA governs the administration of estates of deceased non-Muslims. It can be seen that Singaporean law has specific legislation that governs the Islamic law of succession.

There are also two Acts that regulate the law of succession in South Africa. They are the Intestate Succession $\mathrm{Act}^{26}$ and the Reform of Customary Law of Succession and Related Matters Act. ${ }^{27}$ There has (to date) been no legislation governing or recognising aspects of Islamic law in the South African context despite many attempts in the past to enact such legislation. ${ }^{28}$ The most recent attempt was made in 1999 when the thenMinister of Justice established a committee

"[t]o investigate Islamic marriages and related matters." 29

The committee was referred to as the Project 59 Committee (the Project Committee) and functioned under the re-named South African Law Reform Commission (the Commission). ${ }^{30}$ The investigation started in 1999 and concluded in $2003 .{ }^{31}$ The investigation led to the publication of an Islamic Marriages Bill in 2001 (2001 IMB) and a Muslim Marriages Bill in 2003 (2003 $\mathrm{MMB}$ ). These marriage bills do not specifically deal with the "Islamic" law of succession. The Commission was of the opinion that the issues concerning the Islamic law of succession are complex and manifold. ${ }^{32}$ It was of the

24 Administration of Muslim Law Act 27 of 1966.

25 Intestate Succession Act 7 of 1967.

81 of 1987.

11 of 2009.

28 See Moosa Unveiling the Mind 154.

29 The Project Committee was established in terms of $S 7 A$ of the South African Law Commission Act 19 of 1973: "(1) The Commission may, if it deems it necessary for the proper performance of its functions ... (b) establish such other committees as it may deem necessary, and which shall consist of ... (ii) such members of the Commission as the Commission may designate and the other persons appointed by the Minister for the period determined by the Minister."

30 The Commission was previously referred to as the South African Law Commission (SALC).

31 See Moosa Unveiling the Mind 154.

32 The Institute of Islamic Shari'ah Studies suggested to the Commission that "[p]aragraph (g) ... [should] be added to section 4 of the Intestate Succession Act [81 of 1987 and] should 
opinion that it could not satisfactorily deal with the issues within the scope of its investigation. The Commission noted that there was nothing preventing a Muslim person from ensuring that his or her estate would devolve in terms of Islamic law by executing an Islamic will. ${ }^{33}$

The position is quite similar to the statement in article 110 of AMLA that

"[n]othing in this Act shall be held to prevent any Muslim person directing by his or her will that his or her estate and effects shall be distributed according to the Muslim law."

The Commission made provision to amend the Intestate Succession $\mathrm{Act}^{35}$ by broadening the definition of "spouse" to include a spouse or spouses of a Muslim marriage in the event of the enactment of the 2003 MMB. The Intestate Succession Act is currently not in conformity with Islamic law. The Commission was of the opinion that amending the Act would alleviate the hardships endured by Muslim spouses who in the past had not enjoyed such recognition. ${ }^{36}$ The South African position is thus quite different to the provision in AMLA for a surviving spouse or spouses to inherit in terms of the Islamic law of intestate succession and not in terms of ISA. The definition of a spouse in terms of the South African Intestate Succession Act $^{37}$ has since been developed through the case law. "Spouse" now includes a spouse or spouses from a Muslim marriage.

The 2003 MMB was submitted to the Minister of Justice and Constitutional Development in July 2003 as part of the Commission's report on Islamic Marriages and Related Matters. ${ }^{38}$ The 2003 MMB was subsequently adapted by the Department of Justice and Constitutional Development. It was then presented to Cabinet on 8 December 2010 (2010 MMB). ${ }^{39}$ The provisions in the adapted $2010 \mathrm{MMB}$ regarding succession were no different from the 2003 MMB as neither version deals directly with the Islamic law of succession. However, the provisions in the 2010 MMB do deal with certain liability claims against the deceased estate. Notably, there are a number of South African religious bodies who are pushing for the $2010 \mathrm{MMB}$ to be enacted into legislation. The provisions are noted here for this reason.

read as follows: An estate of a deceased Muslim, whether he or she left a written Will or not and if such a deceased person was married in terms of Islamic law, then such a deceased estate of such a deceased person shall devolve compulsorily upon his or her Muslim heirs and in such shares as prescribed in the Islamic law of Succession. The Master of the High Court is obliged to consult with a proven qualified Muslim Shari'ah jurist therein and obtain a written and duly dated and signed certificate of distribution of such a deceased estate and execute its instructions." See South African Law Reform Commission Project 59 Islamic Marriages and Related Matters Report (2003) 88 www.justice.gov.za/salrc/ reports/r_prj59_2003jul.pdf (accessed 2017-12-23).

33 See South African Law Reform Commission www.justice.gov.za/salrc/reports/r_prj59_2003 jul.pdf.

34 See art 110 of AMLA.

3581 of 1987.

36 See South African Law Reform Commission www.justice.gov.za/salrc/reports/r_prj59_2003 jul.pdf.

3781 of 1987.

38 See SALRC www.justice.gov.za/salrc/reports/r_prj59_2003jul.pdf.

39 See Moosa Unveiling the Mind 159. 


\title{
6 ISLAMIC LAW OF SUCCESSION AND ADMINISTRATION OF ESTATES
}

\author{
Article 112(1) of AMLA states:
}

"In the case of any Muslim person domiciled in Singapore dying intestate, the estate and effects shall be distributed according to the Muslim law as modified, where applicable, by Malay custom."

The wording of the section is broad enough to include a South African Muslim who is domiciled in Singapore. The person who will be administering the estate must apply to the civil courts (not the Islamic courts) for probate or letters of administration. A grant for probate is

\begin{abstract}
"a grant under the seal of the court issuing the same, authorising the executor or executors expressly or impliedly appointed by a testator's will, or one or more of them, to administer the testator's estate in compliance with the directions contained in his will, and in accordance with law.
\end{abstract}

A grant for letters of administration means "a grant under the seal of the court issuing the same, authorising the person or persons therein named to administer an intestate's estate in accordance with law". ${ }^{2}$ The grant for probate and grant for letters of administration could be compared in South Africa to the letters of executorship and letters of authority issued by the Master of the High Court for an Islamic will in which persons were nominated as executors.

The majority of Muslims in Singapore follow the Shaafi'ee school of law. There are, however, other schools of law followed by Singaporean Muslims. Article 113 of AMLA states:

"In all applications for probate or letters of administration the affidavit supporting the application shall, in the case of a deceased Muslim, state the school of law (Mazhab) which the deceased professed in addition to the particulars required by any other written law."

This is quite useful as there are a number of instances where the schools of law differ. Article 114 of AMLA lists a number of books that could be used by the courts in order to decide on matters of succession and inheritance. ${ }^{43}$ This is a good approach as it promotes legal certainty.

40 See also Bin Abbas 2012 Pacific Rim Law \& Policy Journal 177. See also IRB Law LLP Advocates and Solicitors "What You Should Know About Muslim Will in Singapore" https://irblaw.com.sg/ 2017/08/08/what-you-should-know-about-muslim-will-in-singapore/ (accessed 2017-01-08).

41 See s 2 of the Probate and Administration Act 24 of 1934. See also Black "Replicating 'A Model of Mutual Respect': Could Singapore's Legal Pluralism Work in Australia?" 2012 Journal of Legal Pluralism 80.

42 See $s$ of the Probate and Administration Act 24 of 1934.

43 See art 114 of AMLA: "(1) In deciding questions of succession and inheritance in the Muslim law, the court shall be at liberty to accept as proof of the Muslim law any definite statement on the Muslim law made in all or any of the following books: (a) The English Translation of the Quaran, by A. Yusuf Ali or Marmaduke Pickthall; (b) Mohammedan Law, by Syed Ameer Ali; (c) Minhaj et Talibin by Nawawi, translated by E. C. Howard from the French Translation of Van den Berg; (d) Digest of Moohummudan Law, by Neil B. E. Baillie; (e) 
The Islamic will (in the South African context) requires an Islamic law expert to issue an Islamic distribution certificate. The Islamic law expert has quite wide powers as to what opinions should be used when issuing the distribution certificate.

The position could be quite problematic, for example, where $\mathrm{X}$ dies leaving an intestate estate of R600 000.00 and also leaves behind a widower, a mother, a uterine brother, a uterine sister, a full brother, and a full sister as the only intestate beneficiaries. The widower would inherit half (equal to three sixths), ${ }^{44}$ and the mother would inherit one sixth. ${ }^{45}$ The widower would thus inherit R300 000.00 and the mother R100 000.00. The position of the siblings in the above scenario is complicated. ${ }^{46}$

The Shaafi'ee school of law is of the opinion that the uterine brother, the uterine sister, the full sister, and full brother must all share the one third equally. Each of the four siblings would then inherit R50 000.00. ${ }^{47}$ The Hanafee school of law is of the opinion that the uterine brother and uterine sister must share the third equally to the exclusion of the full siblings. ${ }^{48}$ Each of the uterine siblings would then inherit R100 000.00.

The author suggests that a Muslim testator or testatrix (in the South African context) should indicate in his or her will which school of law should be applied when the distribution certificate is drafted by the Islamic law expert. The author would further suggest that an Islamic will should include a clause stating that the same school of law should be applied with regard to repudiation or disqualification of persons in terms of the will. This would ensure that Islamic law consequences would apply in these instances, not South African law consequences.

Anglo-Muhammadan Law, by Sir Roland Knyvet Wilson, 6th Edition Revised by A. Yusuf Ali; (f) Outlines of Muhammadan Law, by A. A. Fyzee; (g) Muhammadan Law, by F. B. Tyabji. (2) The Minister may on the advice of the Majlis by notification in the Gazette vary or add to the list of books set out in subsection (1)."

44 See Khan The Noble Qur'an: English Translation of the Meanings and Commentary $(1404 \mathrm{H})$ ch 4 verse 12 where it states: "In that which your wives leave, your share is a half if they have no child; but if they leave a child, you get a fourth of that which they leave after payment of legacies that they may have bequeathed or debts.'

45 See Khan The Noble Qur'an (4) 11: "For parents, a sixth share of inheritance to each if the deceased left children; if no children, and the parents are the (only) heirs, the mother has a third; if the deceased left brothers or (sisters), the mother has a sixth. (The distribution in all cases is) after the payment of legacies he may have bequeathed or debts."

46 See Khan The Noble Qur'an (4) 12: "If the man or woman whose inheritance is in question has left neither ascendants nor descendants, but has left a brother or a sister, each one of the two gets a sixth; but if more than two, they share in a third; after payment of legacies he (or she) may have bequeathed or debts, so that no loss is caused (to anyone). This is a Commandment from Allah; and Allah is Ever All-Knowing, Most-Forbearing."

47 The opinion of the Shaafi'ee school of law is based on independent reasoning. This question is referred to as the mushtarikah case as the one third is shared between the various classes of siblings. A full brother is generally a residuary beneficiary. See Al Khin and Al Bughaa Al Figh Al Manhajee 'Alaa Madh hab Al Imaam Al Shaafi'ee vol 2 (2000) 400-401.

48 See Al Fawzaan Al Tahqeeqaat Al Mardiyyah Fil Mabaahith Al Fardiyyah (1999) 132-133. 


\section{Liability claims}

Article 112 of AMLA states:

"In the case of any Muslim person domiciled in Singapore dying intestate, the estate and effects shall be distributed according to the Muslim law as modified, where applicable, by Malay custom.

The claims against the estate would therefore include the liability claims that should be deducted in terms of Islamic law. The default marital system for Muslims living in Singapore is that the parties to the marriage retain their separate estates. Article 124 of AMLA states:

"No Muslim person shall, by any marriage contracted in accordance with the provisions of the Muslim law, acquire any interest in the property of the person whom he or she marries nor become incapable of doing any act in respect of his or her own property which he or she could have done if unmarried."

This is similar to a provision found in section 8(1) of the South African 2010 MMB, which states:

"A Muslim marriage to which this Act applies is deemed to be a marriage out of community of property excluding the accrual system, unless the proprietary consequences governing the marriage are regulated by mutual agreement of the spouses, in an ante-nuptial contract which must be registered in the Deeds Registry."

The exception to the marital system is found in Malay custom. Article 112(3) of AMLA states:

"In the case of a Malay dying intestate, the court may make an order for the division of the harta sepencarian or jointly acquired property in such proportions as to the court seems fit."

The widow(s) or widower of a Malay deceased would be eligible to claim from the harta sepencarian and would also be eligible to inherit from the intestate estate in terms of the Islamic law of intestate succession.

The issue of harta sepencarian was raised in the South African context in Ryland $v$ Edros (Ryland)..$^{50}$ The case dealt with the claim of harta sepencarian subsequent to divorce. A share of the same joint property would be claimed subsequent to one of the parties dying. This is also how it applies in terms of article 112(3) of AMLA and why the case should be noted here. The court held that the evidence presented in the case "falls far short of proving that a custom similar to the Malay adat relating to harta sepencarian prevails among the Islamic community in the Western Cape." ${ }^{51}$ The court held (in 1996) that the custom has not been incorporated into the practices of South African Muslims. It has not been confirmed as to whether the Malay

\footnotetext{
See also Bin Abbas 2012 Pacific Rim Law \& Policy Journal 177.

1997 (2) SA 690 (C).

51 See Ryland $v$ Edros supra 717. It should be noted that the Malay adat refers to customary law of the indigenous people of Malaysia and Indonesia. See The Editors of Encyclopaedia Britannica "Adat Malayan and Indonesian Traditional Law" https://www.britannica.com/topic/adat (accessed 2019-06-22).
} 
custom prevails among the Muslim Community in the Western Cape today. ${ }^{52}$ The author would recommend that a testator or testatrix should clearly identify in his or her Islamic will which items (if any) in the estate form part of the joint property. This could alleviate any problems faced by South African Muslims who follow Malay custom in the event that a claim is made against the estate in this regard.

\section{Testate succession claims}

Article 110 of AMLA states:

"Nothing in this Act shall be held to prevent any Muslim person directing by his or her will that his or her estate and effects shall be distributed according to the Muslim law.

Article 111(1) of AMLA states that the will is "subject to the restrictions imposed by the school of Muslim law professed" by the testator or testatrix. ${ }^{54}$ The provision imposes a limitation on freedom of testation, as a testator or testatrix, in terms of the Islamic law of testate succession, is generally not allowed to bequeath more than a third of his or her net estate. This limitation is imposed in terms of legislation. It is interesting to note that a South African Muslim testator or testatrix who executes an Islamic will in terms of the Shaafi'ee or Hanafee (or any other) school of law does so as a matter of choice and not as a matter of compulsion as under AMLA. A will of a South African Muslim is not restricted by Islamic law. It is for this reason that even clauses in a will that are not compliant with Islamic law would be enforceable. It should be noted that a testator or testatrix may not know what the Islamic law rules are. The author therefore suggests that a testator or testatrix, in the South African context should consult with an Islamic law expert in this regard. He or she can then incorporate provisions in his or her will that are compliant with Islamic law.

\section{Intestate succession claims}

Article 115 of AMLA states that a civil court may refer a set of facts to the Syariah Court for a legal opinion as to who the intestate beneficiaries of a deceased estate are. ${ }^{55}$ The Syariah Court would then issue an Islamic

52 Islam was introduced into the Western Cape by Muslims from Indonesia. It is interesting to note that these Muslims were also referred to as Cape Malays. See Moosa Unveiling the Mind 146.

53 See also Bin Abbas 2012 Pacific Rim Law \& Policy Journal 177.

54 See art 111(1) of AMLA: "Notwithstanding anything in the provisions of the English law or in any other written law, no Muslim domiciled in Singapore shall, after 1st July 1968, dispose of his property by will except in accordance with the provisions of and subject to the restrictions imposed by the school of Muslim law professed by him."

55 The Syariah Court is one of the organs established in terms of AMLA. See art 34 of AMLA: "The President of Singapore may by notification in the Gazette constitute a Syariah Court for Singapore." See also Steiner 2016 Australian Journal of Asian Law 12. See also Syariah Court Singapore "Inheritance Certificate" https://www.syariahcourt.gov.sg/Syariah/frontend/Default.aspx?pid=M03.01 (accessed 2018-01-08). 
distribution certificate ${ }^{56}$ The provision also permits the beneficiary of a deceased estate to apply for an Islamic distribution certificate. There is a prescribed fee that must be paid. ${ }^{57}$ South Africa has (to date) not enacted any legislation governing the Islamic law of intestate succession. A case concerning an Islamic distribution certificate was heard in the Western Cape Division of the High Court of South Africa in $2017 .^{58}$ The certificate came about as a result of a clause found in an Islamic will that directed that the estate should devolve in terms of Islamic law and that an Islamic distribution certificate issued by the Muslim Judicial Council (SA) or any other recognised Muslim judicial authority shall be final and binding in this regard. The Muslim Judicial Council (SA) is based in the Western Cape, South Africa, and primarily follows the Shaafi'ee school of law. The Muslim Judicial Council (SA) issued the Islamic distribution certificate in terms of the clause. It should be noted that the South African law of intestate succession would have applied if the deceased had not left behind an Islamic will.

The process followed in order to obtain an Islamic distribution certificate by the Syariah Court in Singapore is quite similar to the process followed to obtain an Islamic distribution certificate issued by the Muslim Judicial Council (SA) based in the Western Cape. The difference between Singapore and South Africa is that the inheritance certificate in Singapore is based on AMLA and a request made to the Syariah Court, whereas the Islamic distribution certificate in South Africa is based on freedom of testation and a clause in the will of the testator or testatrix requiring an organisation like the Muslim Judicial Council (SA) to issue an Islamic distribution certificate. The difference between the position in Singapore and South Africa is that Singapore requires that the school of law followed by the deceased should be followed. It is submitted that South Africa should follow the same approach as far as the Islamic will is concerned.

56 It should be noted that the term "inheritance certificate" is used in the Singaporean context whereas the term "Islamic distribution certificate" is used in South Africa.

57 See art 115 of AMLA:"(1) If, in the course of any proceedings relating to the administration or distribution of the estate of a deceased person whose estate is to be distributed according to the Muslim law, any court or authority shall be under the duty of determining the persons entitled to share in such estate or the shares to which such persons are respectively entitled, the Syariah Court may, on a request by the court or authority or on the application of any person claiming to be a beneficiary and on payment of the prescribed fee, certify upon any set of facts found by such court or authority or on any hypothetical set of facts its opinion as to the persons who are, assuming such facts, whether as found or hypothetical, entitled to share in such estate and as to the shares to which they are respectively entitled. (2) The Syariah Court may, before certifying its opinion, require to hear the parties on any question of law, but shall not hear evidence or make findings on any question of fact."

58 See Moosa N.O. v Harnaker 2017 (6) SA 425 (WCC), and Moosa N.O. v Minister of Correctional Services 2018 (5) SA 13 (CC). See also Abduroaf "An Analysis of Renunciation in Terms of $\mathrm{s}$ 2(C)(1) of the Wills Act 7 of 1953 in Light of the Moosa NO and Others v Harnaker and Others Judgment" 2019 Electronic Journal of Islamic and Middle Eastern Law for a discussion regarding the case. 


\section{$7 \quad$ CONCLUSION}

This article has compared the application of the Islamic law of succession and administration of estates in Singapore with its application in South Africa. It has looked at the constitutional and international law obligations of these two countries with regard to prohibition of discrimination. This was important as the Islamic law of intestate succession states, for example, that a daughter inherits half the share of a son. The discussion has shown that Singaporean law places more importance on the right to freedom of religion than on the right to equality, whereas the reverse is true in South African law. It could be argued that the former value system was the reason for the successful enactment of Islamic law of succession legislation (which includes the Islamic law of intestate succession) in Singapore and that the latter is the reason that the Islamic law of succession has to date not been incorporated into South African legislation.

This article has shown that certain features found in the Singaporean model can be applied in South Africa in the absence of legislation regulating the Islamic law of succession. Suggestions have been made throughout this article in this regard but they are summarised here for purposes of completion.

A Muslim testator or testatrix should approach an Islamic law expert if he or she intends bequeathing items in his or estate in terms of Islamic law. The bequest can then be inserted in an Islamic will. The will should state that the claims against his or her estate must be dealt with in terms of Islamic law and according to the school of law that he or she states in the will. These would be liability claims, testate succession claims and intestate succession claims. The will should state that the liability claims against his or her estate (at the time of his or her death) must be ascertained by his or her executor or executrix in terms of Islamic law and in terms of the school of law stated in the will and should be deducted from the gross estate. The executor should approach an Islamic law expert in this regard in order to ascertain what these liabilities are. The testator or testatrix may then incorporate a bequest (if any) in the will according to the advice given by the Islamic law expert. The will should then state that the remainder of the estate must be distributed in terms of the Islamic law of intestate succession. The will should also state that the executor or executrix must approach an Islamic law expert to issue an Islamic distribution certificate in terms of the school of law that the testator or testatrix has stated in his or her will. The will should further state that all aspects regarding repudiation and disqualification of beneficiaries are to be dealt with in terms of Islamic law and not in terms of South African law, and that a certificate issued by an Islamic law expert shall be final and binding in this regard. 